\title{
Numerical analysis of reinforced concrete beams pre-cracked reinforced by composite materials
}

\author{
Fatima Benaoum, Foudil Khelil, Ali Benhamena \\ University of Mascara, Laboratory of Quantum Physics of Matter and Mathematical Modeling (LPQ3M), Mascara 29000, \\ Algeria. \\ Benkatrine2008@yahoo.fr,khelilfoudi@yahoo.com,ali_benhamena@yahoo.fr
}

\begin{abstract}
The mechanical properties of concrete and steels are likely to deteriorate depending on the environmental conditions defined by the geographic location of infrastructures in civil engineering. In this field, external bonding of FRP plates or sheets is one of the most popular methods for strengthening reinforced concrete structures. This paper focuses on the application of three-dimensional finite element method (3D-FEM) in order to study the effect of some parameter on the failure by delamination of repaired cracked concrete beams in the first part. In the second part, we focused to study the effects of adding of steel fiber in concrete and its volume fraction on the load-deflection response of concrete. The level of ultimate load is examined of patched and unpatched concrete beams. The results also showed that the flexural-deflection response vary with volume fractions of fibers compared to witness beam (without reinforcement). The effects of the loading magnitude, crack initiation, mechanical properties and geometrical parameters were highlighted.
\end{abstract}

KEYWORDS. Reinforced concrete; Pre-cracked beams; Composite materials; FRP plate; Deflection; 3D-FEM; Three point bending.

\section{OPEN $\bigcirc$ ACCESS}

Citation: Benaoum, F., Khelil, F., Benhamena, A., Numerical analysis of reinforced concrete beams pre-cracked reinforced by composite materials, Frattura ed Integrità Strutturale, 54 (2020) 282-296.

Received: 02.05 .2020

Accepted: 08.09.2020

Published: 01.10.2020

Copyright: (C) 2020 This is an open access article under the terms of the CC-BY 4.0 which permits unrestricted use, distribution, and reproduction in any medium, provided the original author and source are credited.

\section{INTRODUCTION}

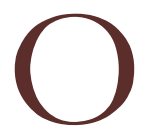

ver the years, mankind has used the most diverse materials (wood, clay and concrete) to build their homes since the dawn of human civilization. In the whole world, reinforced concrete is the most used structure in all types of building, including metallic ones, for the execution of foundations, pavements, bridges, water and sewage systems and marine constructions. Given that the concrete has proven to be a resistant material and has a high durability. On the other hand, it is known that, a numerous local defects in concrete can be occur during and after construction. During construction bad consolidation can leave air voids or concrete may be cracked during curing and consequently the concrete structures have suffered premature failure. In order to extend the life of mixed structural (concrete + steel) it is necessary to rehabilitate the reinforced concrete RC. There are several techniques for the rehabilitation, the use of externally applied fiber-reinforced polymers (FRP) has gained significant popularity for strengthening and repair of 
concrete structures according to Benzaid et al. [1]. This latter also showed that the CFRP wrap increases the strength and ductility of plain- and reinforced-concrete (RC) cylinders significantly. Sereir et al. [2] performed the volume optimization of a RC beam reinforced externally by FRP plate using the non linear finite element method, while Tounsi et al. [3] and Benachour et al. [4] presented a simplified solution for interfacial stresses in a concrete beam bonded with the FRP plate by including the effect of the adherent shear strain. In the same context, an iterative design optimization procedure of flexural stiffness profiles was proposed by Sebastian [5], in order to determine the maximum load that generates the appearance of cracks. An algorithm of the iterative procedure was coupled with a numerical model by finite elements of a real structure in reinforced concrete hyperstatic in bending reinforced by FRP. Perera et al. [6] developed an artificial neural network in order to predict the shear strength of concrete beams reinforced with FRP-plates. They demonstrated also, that the neural network is able to predict the experimental trend. Kato et al. [7] studied the structural ductility of the reinforced fiber composites applying an optimization method; they used this method for calculation of damages structural behavior of reinforced concrete. Bruggi et al. [8] have developed an original approach based on topology optimization of any unidirectional fiber-reinforcement to improve the structural performance of existing structural elements and they reported an increasing in bearing capacity of reinforced beams compared to the unreinforced beams. Madi and Guenfoud [9] experimentally verified that the rehabilitations of reinforced concrete columns by confinement with FRP fabric reveal a considerable gain in resistance and strain capacity of reinforced sections. Hadjazi et al. [10] used a cohesive zone model to evaluate the interfacial shear stresses and its effects in the debonding mechanisms in FRP rehabilitated concrete. Lusis et al. [11] carried out a series of tests and numerical analysis to study the effect of insertion of short fibers on the mechanical properties of reinforced concrete. They have shown a significant impact on tensile strength of structure. Spadea et al. [12] examined the strength and ductility aspects of reinforced concrete (RC) beams strengthened with an externally CFRP laminates, they found that the bonding of CFRP laminate at the tension face of RC beams affected significantly the deflection and energy of the strengthened composite beam. Also, Bennegadi et al. [13] developed a numerical model for the optimization of the external reinforcement of reinforced concrete beams by HFRP Plate, again, they have found, that the ultimate load of the reinforced concrete beam is raised compared to the reference beam and the geometrical and mechanical parameters of the HFRP plate must be optimized. A further examination of this subject can be found in Refs. [14-19]. Hashemi et al. [20] presented an experimentally and numerically of flexural behavior of FRP-strengthened RC beams using cement-based adhesives and concluded that the use of cement-based bonding materials is a promising technique in FRP applications for structures located in hot regions or in danger of fire, because the epoxy-bonded loses their mechanical strength at high temperatures. In other words, it will be beneficial if they can be replaced the epoxy by cementitious (mineral)-based bonding agents such as modified concrete to achieve on applications of these structures when the operating conditions are quite severe. Kermiche and Redjel [21] presented an experimental study and analytical model in order to simulate the mechanical behavior and crack initiation of concrete and reinforced concrete. Tabatabaei et al [22] investigated experimentally the effect of addition of long carbon fibers as a method to improve the impact spalling resistance of concrete. They indicated that the strain energy is affected by adding of long carbon fibers and are found to be 4-20 times higher than that of plain concrete. A further experimental and numerical investigation have been carried out by Narmashiri et al. [23] on the failure analysis and structural behaviour of CFRP strengthened steel I-beams. They have concluded that the load bearing capacity has influenced by the CFRP plate geometric and its mechanical properties. Hallonet et al. [24] investigated the mechanical and durability performance of wet lay-up flax/ epoxy composites used for the external strengthening of concrete structures and concluded that the glass and flax composites present comparable tensile stress at failure and the mechanical properties of the composites are lower after hydrothermal ageing than after climatic ageing. Asgarinia et al. [25] investigated the fatigue behaviour of woven flax/epoxy composites and they concluded that the flax fibres present a good performance and strength compared to those exhibited by glass fibres. In particular they revealed also, that the use of flax/epoxy composites should be favoured in load-bearing applications. Also, Ivanova et al. [26] performed an experimental analysis of strengthened reinforced short concrete corbel by using carbon fabrics. From these study, they showed that strengthened reinforced concrete corbel bonded by carbon fiber fabrics can improve the ultimate load to twice and stiffens less than a third. Numerous experimental studies have shown that the use of supplementary cementing materials such as granulated blast furnace slag, fly ash, silica fume and natural pozzolans as partial replacement of portland cement are fundamental parts of high strength concrete in order to increase their mechanical properties [27-30]. Lijuan et al. [31] analysed experimentally the effect of adding of low volume of tire rubber particles in mechanical properties of concrete. The authors concluded that the adding of rubber reduces the axial compressive strength of concrete. Moreover, they showed also, that the increasing the rubber content and decreasing the size of rubber particles lead to decrease in axial compressive strength and elastic modulus of RC. Similar results were found by Bompa et al. [32] who found that the increase in rubber content decrease the compressive strength, elastic modulus, and crushing strain. Based on the above, it can be noted that durability and the recovery of concrete structures 
are issues that concern the community in general and, therefore, that the complete mastery of methods and techniques for the rehabilitation of structures is of national and worldwide interest. These facts lead the authors to focus of the current study, in order to contribute in this way. In addition the reinforcement processes for concrete structures is not fully understood and represent a very active research field. The use of the finite element method in engineering projects has evolved a lot in recent years, mainly due to the use of numerical methods in commercial software. Finite Element Analysis (FEA) is an important tool to design a structural component in civil engineering, such as the field of reinforced concrete structures. In the present study the 3D-FEM based on the analysis of load-deflection response is examined in reinforced concrete beams. The effects of the loading magnitude, crack initiation and the geometrical parameter were highlighted. Two examples are presented: in the first section, a cracked concrete beam strengthened by externally bonded FRP-plates (CFRP) and secondly, a concrete beam reinforced by steel bars (reinforced concrete: RC)

\section{FRACTURE ENERGY OF CONCRETE}

7 he fracture energy of concrete is determined by a three-point bend test according to Petersson [33]. It is determined as the area under the entire measured load-deflection curve (Fig. 1), divided by the ligament area according to Bažant and Giraudon [34] with the fracture energy, $G_{f}$, corresponding to the area under the initial tangent of the softening stress-separation curve of cohesive crack model, which governs the maximum loads; while the fracture energy, $G_{F}$, corresponding to the area under the complete stress-separation curve, which governs large post-peak deflections of structures. Planas and Elices [35] estimated $G_{F} / G_{f}=2.0 \simeq 2.5$, the ratio of $G_{F} / G_{f}$ equal to 2.5 was taken in our study.

$$
\frac{G_{F}}{G_{f}}=2.5
$$

If experimental data are not available in literature and according to ASTM [36], the elastic modulus of concrete can be expressed by concrete compressive strength as follow:

$$
\mathrm{E}_{\mathrm{c}}=4700 \sqrt{\mathrm{f}_{\mathrm{c}}}
$$

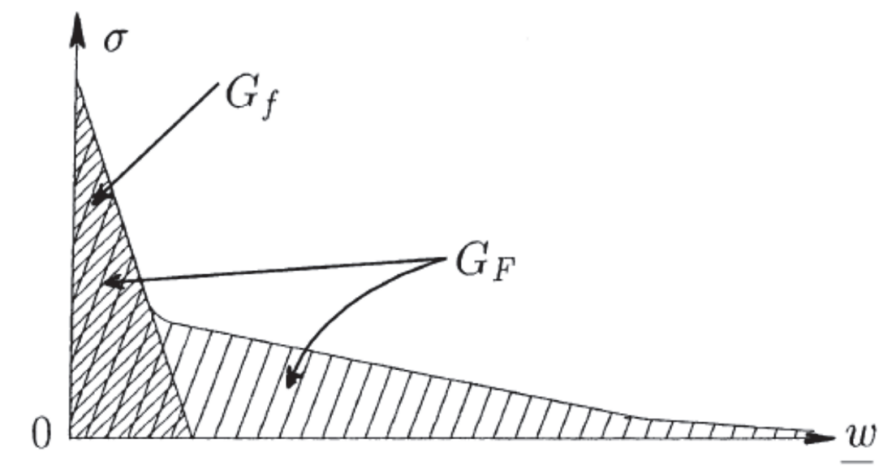

Figure 1: Softening stress-separation curve of cohesive crack model and areas representing $G_{\mathrm{f}}$ and $G_{\mathrm{F}}$.

Also, in finite element simulations, if no test data are available, $\mathrm{G}_{\mathrm{F}}$ may be estimated bases on the analysis of Wu and Niu [37] from the following equation:

$$
\mathrm{G}_{\mathrm{F}}=0.644 \mathrm{f}_{\mathrm{c}}^{0.19}
$$

From Eqn. (1) and Eqn. (2), we have 


$$
\begin{aligned}
& G_{f}=0.4 G_{F} \\
& f_{c}=\left(\frac{E_{c}}{4700}\right)^{2}
\end{aligned}
$$

Substituting Eqn. (4) and Eqn. (5) into Eqn. (3), we have

$$
G_{f}=(0.4)(0.644)\left[\left(\frac{E_{c}}{4700}\right)^{2}\right]^{0.19}
$$

and finally the fracture energy $G_{f}$ can be expressed by the concrete modulus of elasticity $E_{c}$, as follow for this concrete:

$$
G_{f}=0.2576\left(\frac{E_{c}}{4700}\right)^{0.38}
$$

\section{DESCRIPTION OF FINITE-ELEMENT AND MATERIAL MODELS OF (CFRP)}

his work aims to contribute to the study the fracture behaviour of mixed structure. The finite element procedure implemented in this study through the development of parameterized routines written in the APDL (Ansys Parametric Design Language) programming language for the software ANSYS, which are capable of satisfactorily simulating the behaviour of these structural components. The goal of this paper is to study the behavior of concrete beams strengthened by externally bonded FRP-plates by the computation of load versus mid-span deflection considering a SENB concrete beam having varied the ratio of crack length to width of beam (a/W). The concrete is modelled using SOLID65 element type [38]. This element has eight nodes with three degrees of freedom at each node ; translations in the nodal $\mathrm{x}, \mathrm{y}$, and $\mathrm{z}$ directions. This element is capable of plastic deformation, cracking in three orthogonal directions, and crushing. All the concrete beam were loaded in a Three-point bending (Fig. 2a). Nonlinear behaviour of the geometry and materials properties for the concrete structures was considered in this study. Concrete is a quasi-brittle material and has a

\begin{tabular}{|c|c|c|c|c|c|c|}
\hline \multicolumn{7}{|c|}{ Geometrical parameters } \\
\hline $\mathrm{L}_{1}(\mathrm{~mm})$ & $\mathrm{L}_{2}(\mathrm{~mm})$ & $\mathrm{L}_{\mathrm{p}}(\mathrm{mm})$ & $\mathrm{w}(\mathrm{mm})$ & $\mathrm{B}(\mathrm{mm})$ & $\mathrm{e}_{\mathrm{a}}(\mathrm{mm})$ & $\mathrm{e}_{\mathrm{p}}(\mathrm{mm})$ \\
\hline 210 & 280 & 180 & 70 & 70 & 2 & 2 \\
\hline \multicolumn{7}{|c|}{ Material properties } \\
\hline Materials & & CFRP plate & & & \multicolumn{2}{|c|}{ Adhesive layers } \\
\hline $\mathrm{E}(\mathrm{GPa})$ & & 43.5 & & & \multicolumn{2}{|c|}{3.80} \\
\hline Poisson's ratio & & 0.33 & & & \multicolumn{2}{|c|}{0.35} \\
\hline
\end{tabular}
highly nonlinear and ductile stress-strain relationship. The geometric dimensions of the specimen and the mechanical properties of concrete, FRPs plate and adhesive are selected according to several references [10, 13, 39-40] and are given in Tab. 1 .

Table 1: Geometric and material properties [10, 13, 39-40]

Finite element simulation was done using the commercial software ANSYS $($ ANSYS 19 [38]). The numerical simulation of delamination and crack growth in three-dimensional is known delicate for reasons related to the mesh at the interface and in the vicinity of the crack, especially when dealing with the reinforcement of concrete beams by FRP.

The mesh of the concrete beams with FRP is composed of several regulated zones. The mesh is designed to be highly refined in the interface and near the crack-tip in order to obtain more accurate results (typical element dimension in these 
zone is $0.05 \mathrm{~mm}$ ). Various mesh schemes are tried to achieve convergence. The optimized model has 18,263 nodes, 18,200 elements. The mesh model with the boundary and loading conditions are given in Fig. 2b. The theory of incremental plasticity is introduced to modelling the material nonlinearity. The iterative method of Newton-Raphson is used as an approach to solve nonlinear equations by finite elements.

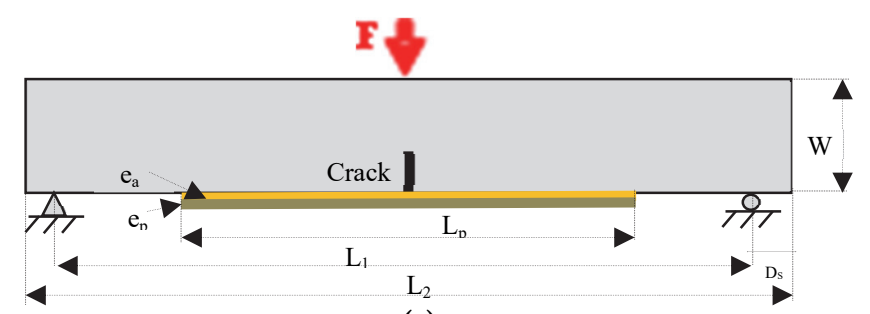

(a)

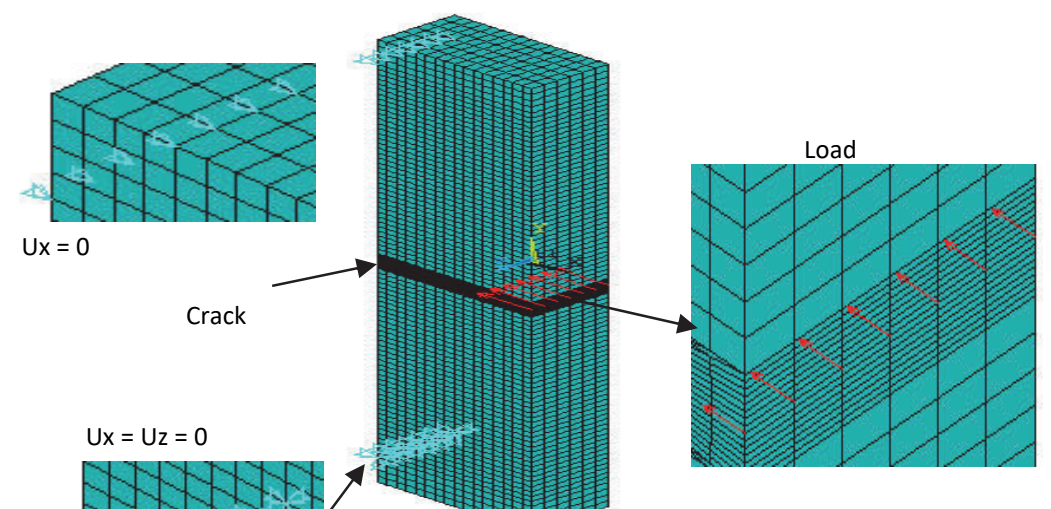

(b)

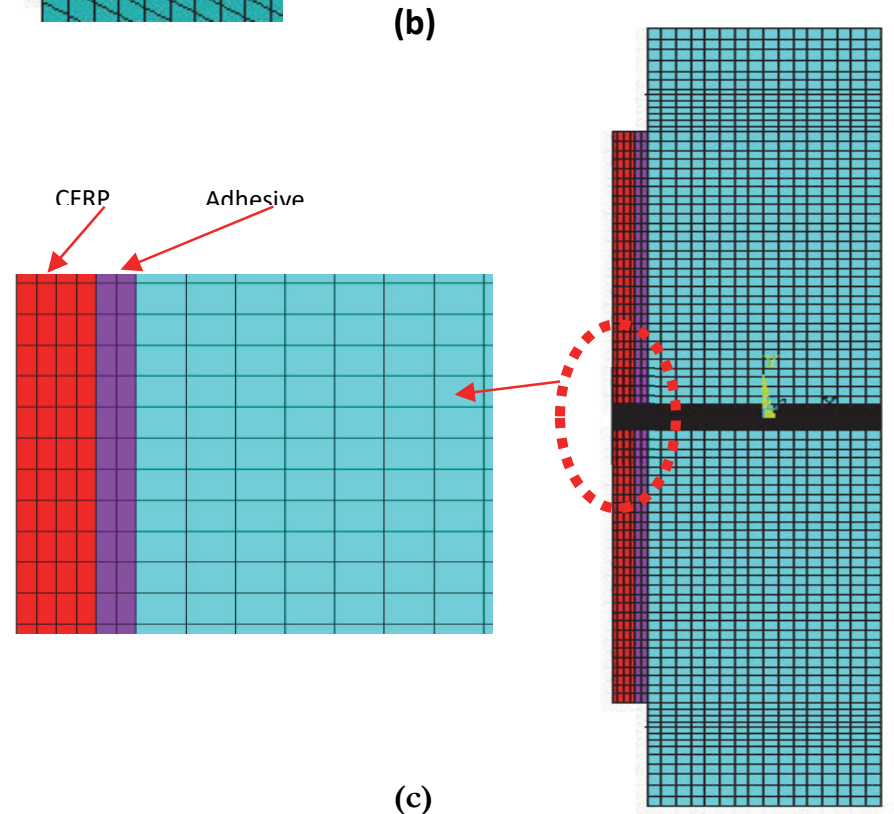

Figure 2: (a); Illustration of the specimen geometry with the boundary conditions and loading condition, (b) Meshing of unpatched cracked specimen and (c) Meshing of patched cracked specimen. 


\section{Results and discussion}

The curves of load versus mid-span deflection of the uncracked beams, unpatched and patched cracked beams are shown in Fig. 3 . These results show that, the shape of any load-deflection curve is similar with respect the crack size. It's also showed a bi-linear behavior: a precracking (elastic behavior) and post cracking behavior up until total failure (appearance and the development of the damage within the volume of the material). Furthermore, a significant differences are noticed concerning the witness and cracked beams especially when the crack becomes longer (Fig. 3a). This behavior may be explained by the fact that the change of the crack length lead to increasing of the stress level at the near the crack front, which reduce the stiffness of beam. Fig. 3b, c and d also reveals, that the use of externally bonded FRP-plates in concrete beams increases the ultimate strength and stiffness of structures regardless the crack size. In other words, a transfer of stress level from the crack tip to the patch through the adhesive, which lead to increases of beam stiffness and consequently to the improve of the performance of infrastructures in service.

(a)

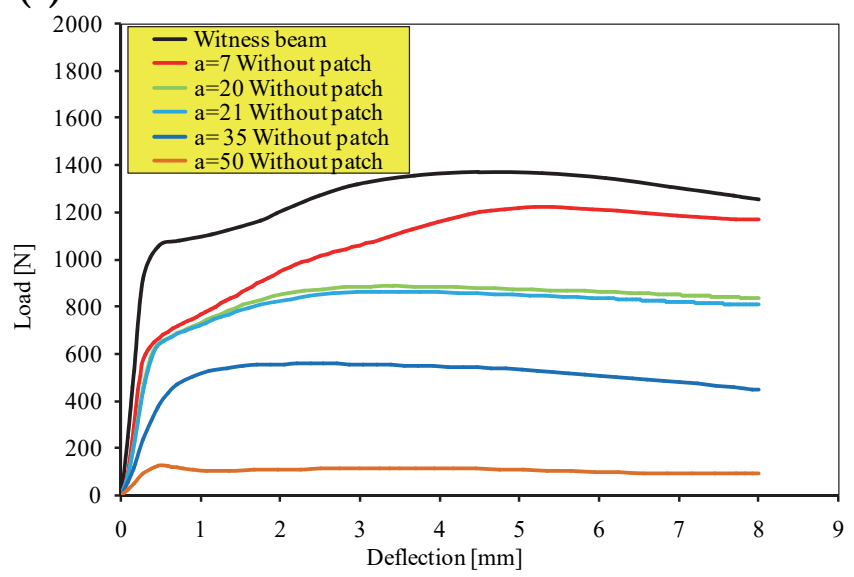

(c)

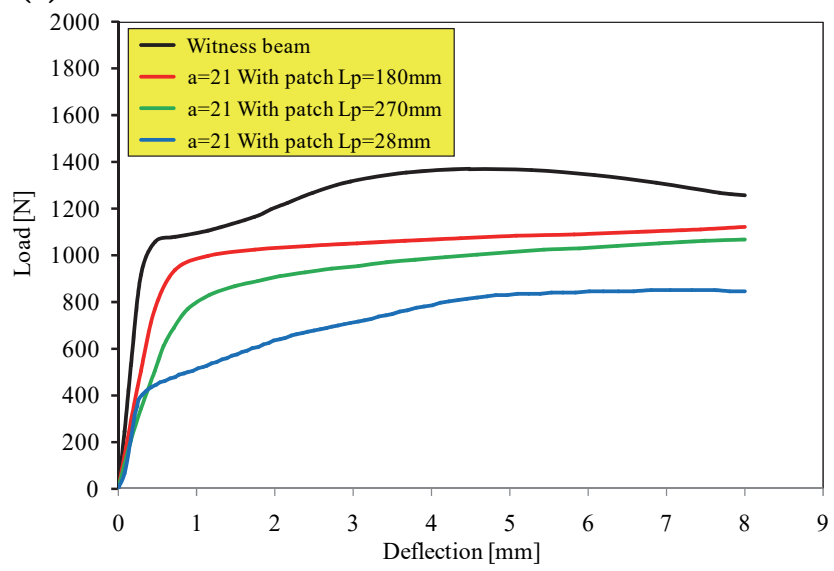

(b)

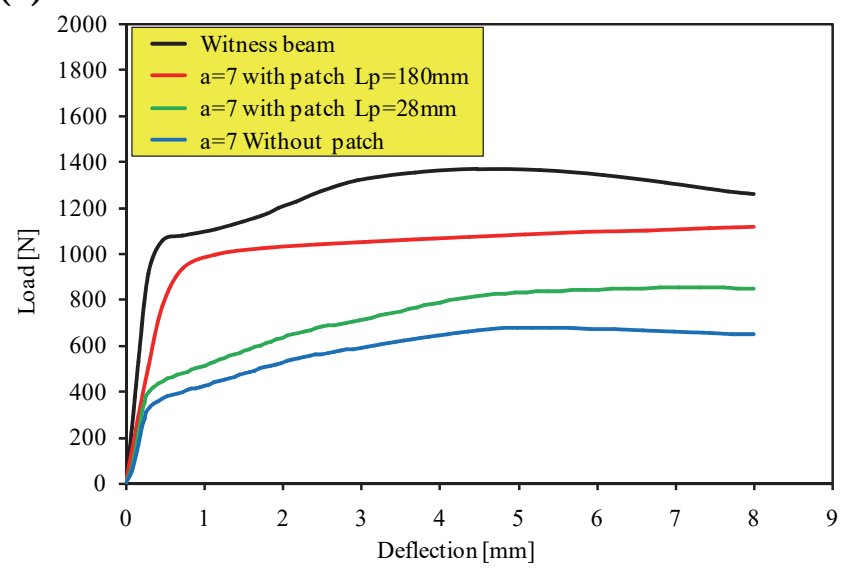

(d)

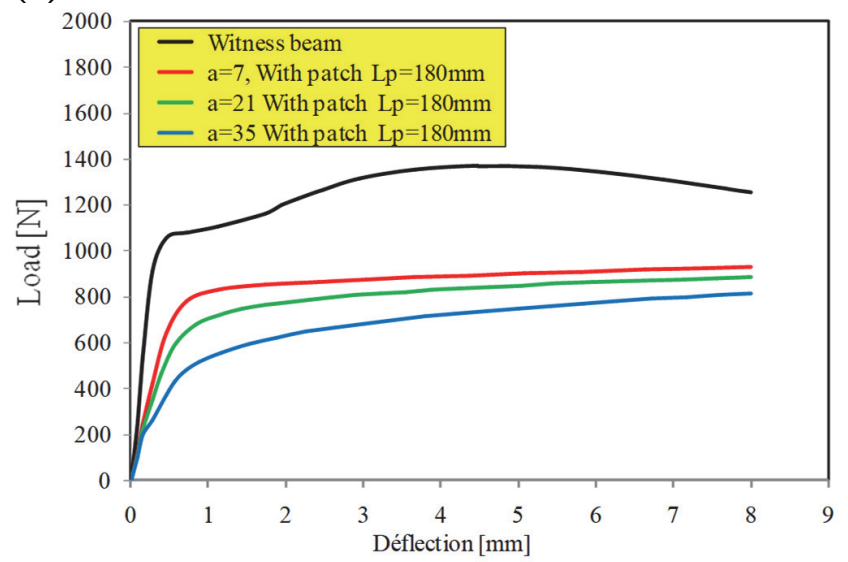

Figure 3: Comparison of the load vs. mid-span deflection of uncracked and cracked beam: (a) varied crack lengths a without patch (b) $\mathrm{a}=7 \mathrm{~mm}$ and varied $\mathrm{Lp},(\mathrm{c}) \mathrm{a}=21$ and varied $\mathrm{Lp},(\mathrm{d}) \mathrm{Lp}=180 \mathrm{~mm}$ and varied $\mathrm{a}$.

Fig. 4 shows the variations of load as a function of the mid-span deflection for various patch length $(\mathrm{L})$ for three values of crack size $(\mathrm{a}=7,21$ and $35 \mathrm{~mm})$. It is appear from these figures that the geometry of the patch has a great effect on the beam stiffness, a decrease of patch length leading to reduce to the beams resistance. This behavior can be explained by the fact that the patch absorbs the stresses in the cracked zone. As the patch length increases implying that the damage developed in patched beam is very slowly. 
(a)

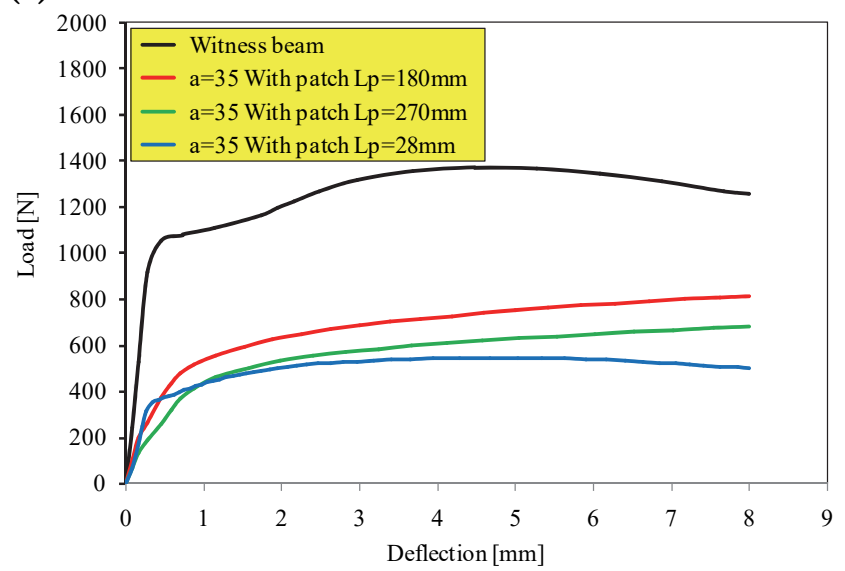

(b)

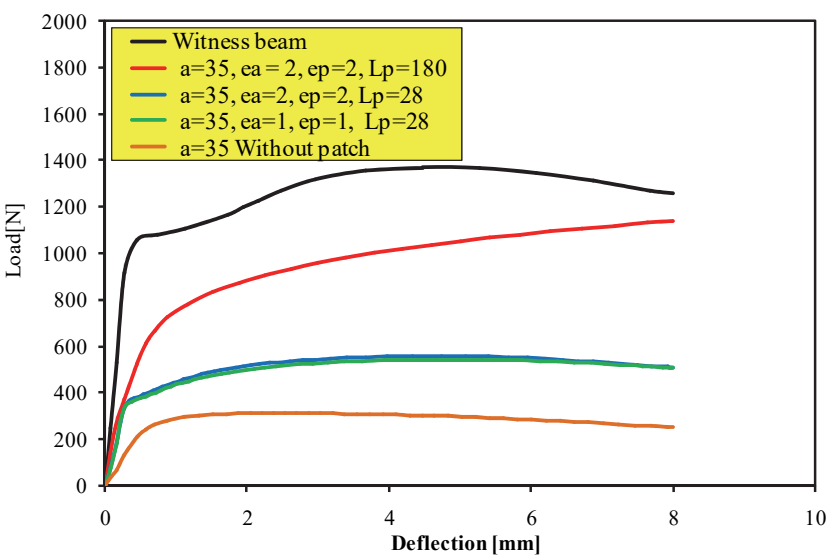

Figure 4: Comparison of the load vs. mid-span deflection of: (a) effect of patch length $\mathrm{L}_{\mathrm{P}}$, (b) effect of patch length $\mathrm{L}_{\mathrm{P}}$ and adhesive thickness.

(a)

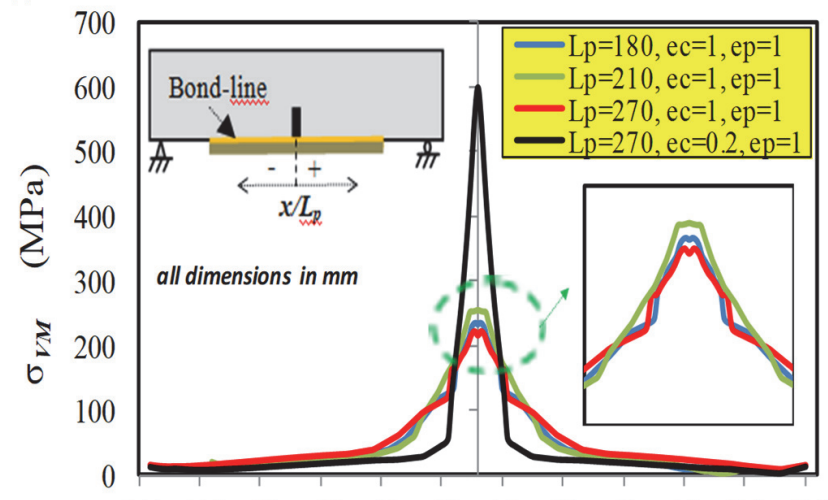

$\begin{array}{llllllllllll}-140 & -115 & -90 & -65 & -40 & -15 & 10 & 35 & 60 & 85 & 110 & 135\end{array}$

Normalized position $(x / L p)$

(c)

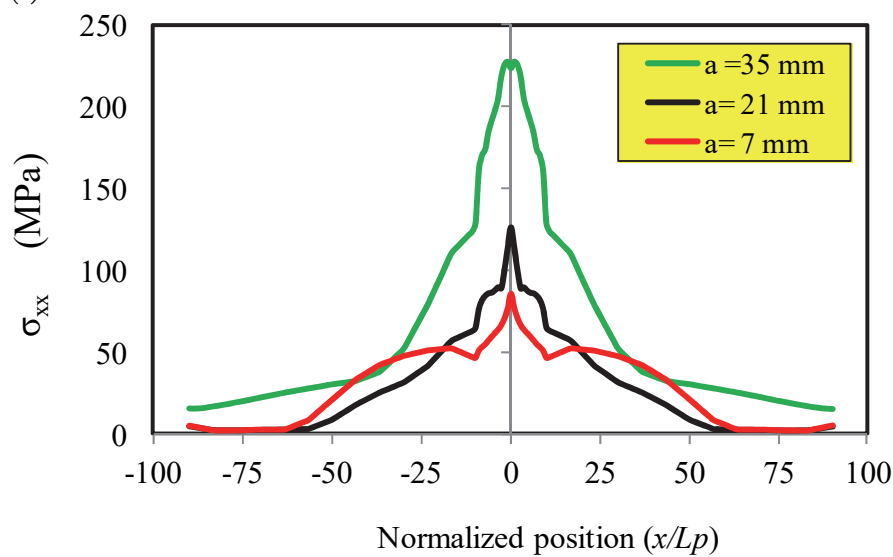

(b)

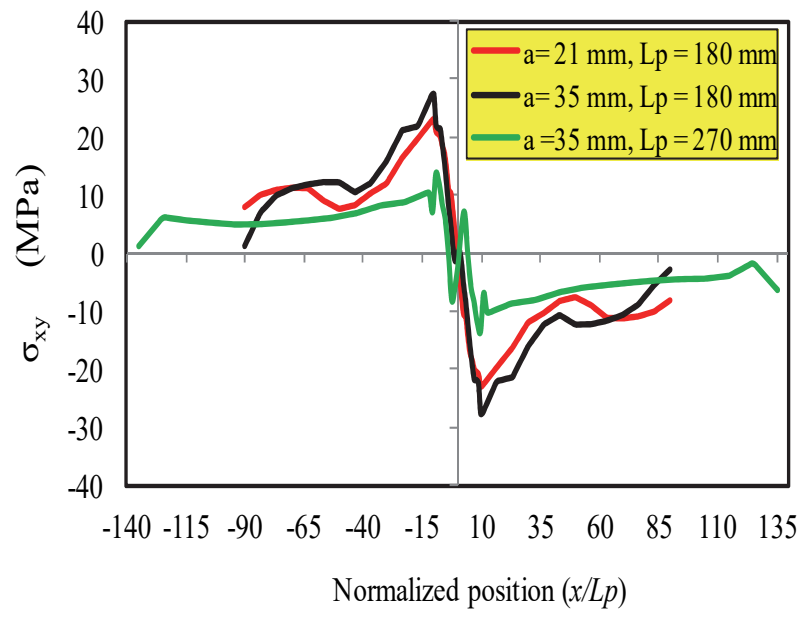

(d)

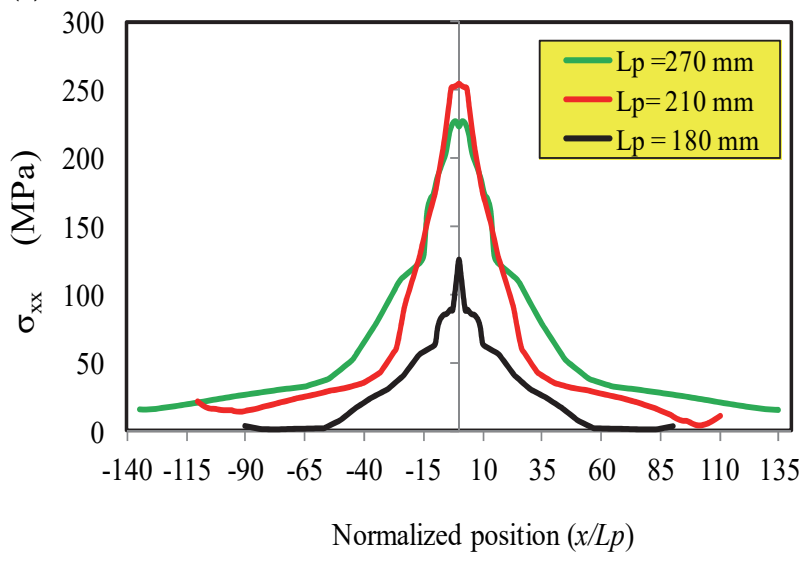

Figure 5: Evolution of interfacial Stresses along the bond line: (a) effect of patch length and adhesive thickness on the Von Mises stress, (b) effect of patch and crack lengths on the shear stress, (c) effect of crack length on the normal stress, (d) effect of patch length on the normal stress. 


\section{Parametric study}

It is known that the failure modes of RC beams reinforced by externally bonded FRPs plates is related to mechanical properties and geometrical parameters of adhesive and FRPs plate according to Gao et al. [41]. To do this, this numerical study is made in order to determine the effect of such parameters: crack size, patch length and adhesive thickness on the distribution of interfacial stresses and deflection along the bond line.

Fig. 5.a-d shows that the interfacial stresses (the Von-Mises stress, the shear and normal stresses) are clearly influenced by the variation of geometrical parameters such as: length and thickness of the patch, adhesive thickness and the crack size. In other words, the increasing of patch length leads to decreasing of the Von-Mises stress (Fig 5.a) and to increasing of the normal stress at the Interface between the concrete and the adhesive (Fig 5.c-d), while a large crack size leads to higher shear stress (Fig 5.b). The presence of high level stresses under the flexural crack provides an explanation to the propagation by delamination. We recall also, that the delamination is related to the level of interfacial stresses [2-3].

(a)

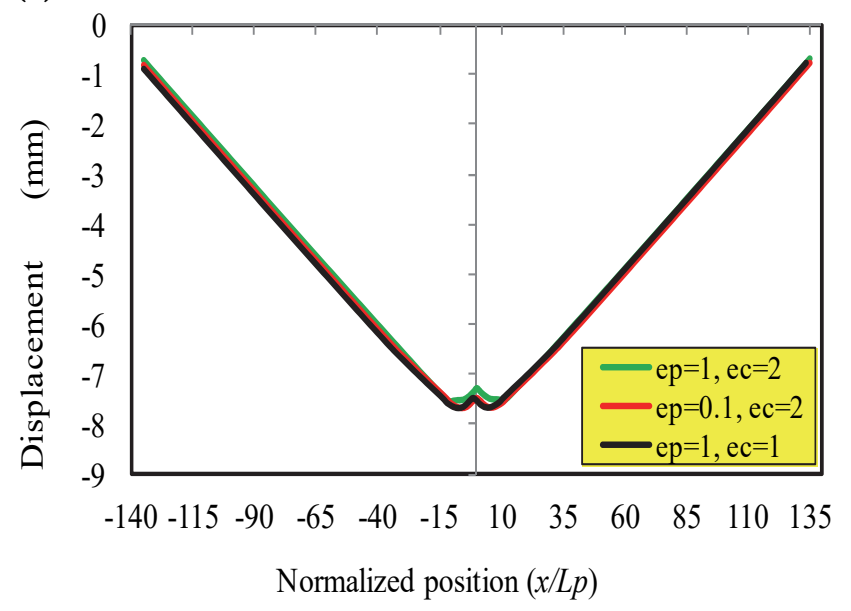

(c)

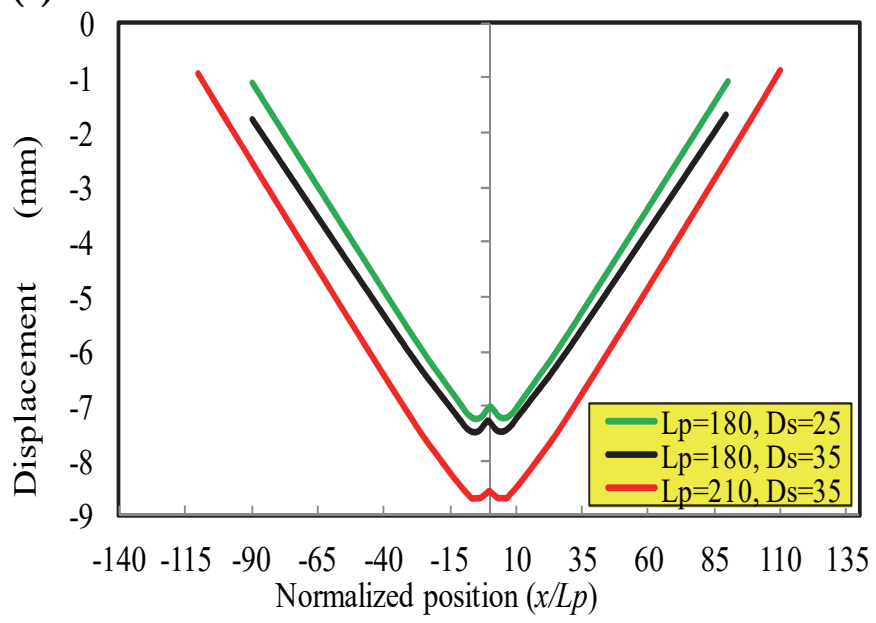

(b)

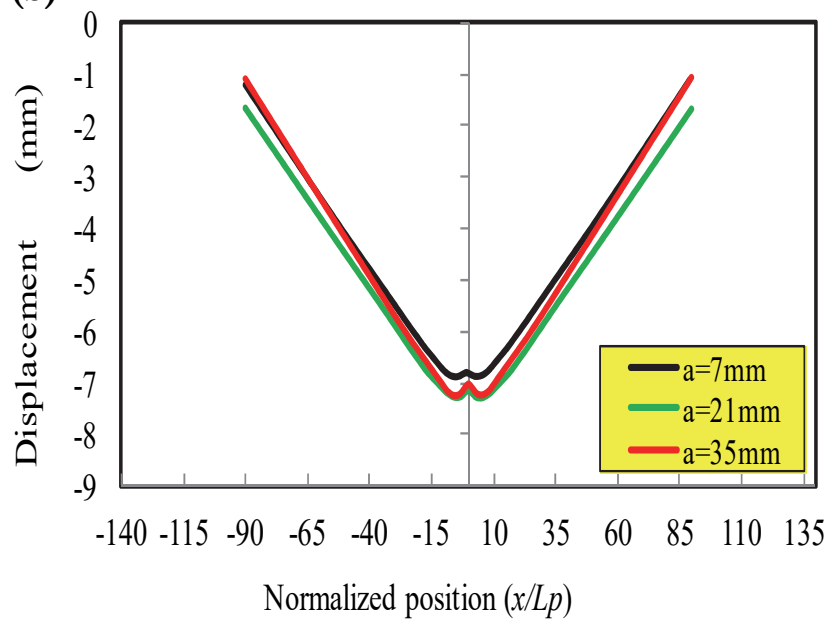

(d)

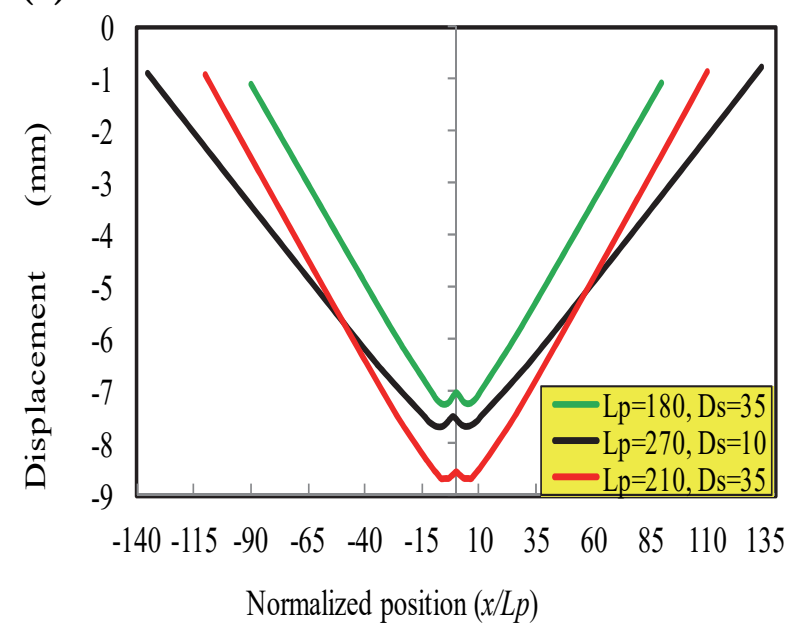

Figure 6: Evolution of deflection along the bond line: (a) effect of adhesive thickness, (b) effect of crack size, (c) effect of patch length, (d) effect of span length Ds

The evolution of deflection along the bond line are presented in Fig. 6a, b, c and d. Again, the effect of adhesive thickness is practically negligible on the value of deflection (Fig. 6a). However, the crack size and patch length has a great effect on the deflection at level of both lips of the crack (Fig. 6b-d). This behavior can be explained probably by the fact that the presence of this very high deflection at this location (at the two sides of a crack) can favor the crack growth by delamination which leads to an unexpected rupture by the presence of the loading of service. 


\section{GEOMETRICAL MODEL AND MATERIAL PROPERTIES OF REINFORCED CONCRETE (RC)}

$\mathrm{I}$ $\mathrm{n}$ this part, we are interested in the study of the efficiency of the adding of conventional steel bars in a concrete beam under three-point bending load. The concrete beam and supports were modeled as volumes. The dimensions and combined volumes of the support and beam are shown in Fig. 7a. A reinforced concrete beam is a $750 \mathrm{~mm}$ in length with cross section of $150 \mathrm{~mm} \times 100 \mathrm{~mm}$ (depth x width) and a span of $700 \mathrm{~mm}$ is considered in this study. This beam is made of $10 \mathrm{~mm}$ diameter steel bars and they used as the main tensile bars and of $6 \mathrm{~mm}$ diameter steel stirrups at $120 \mathrm{~mm}$ spacing.

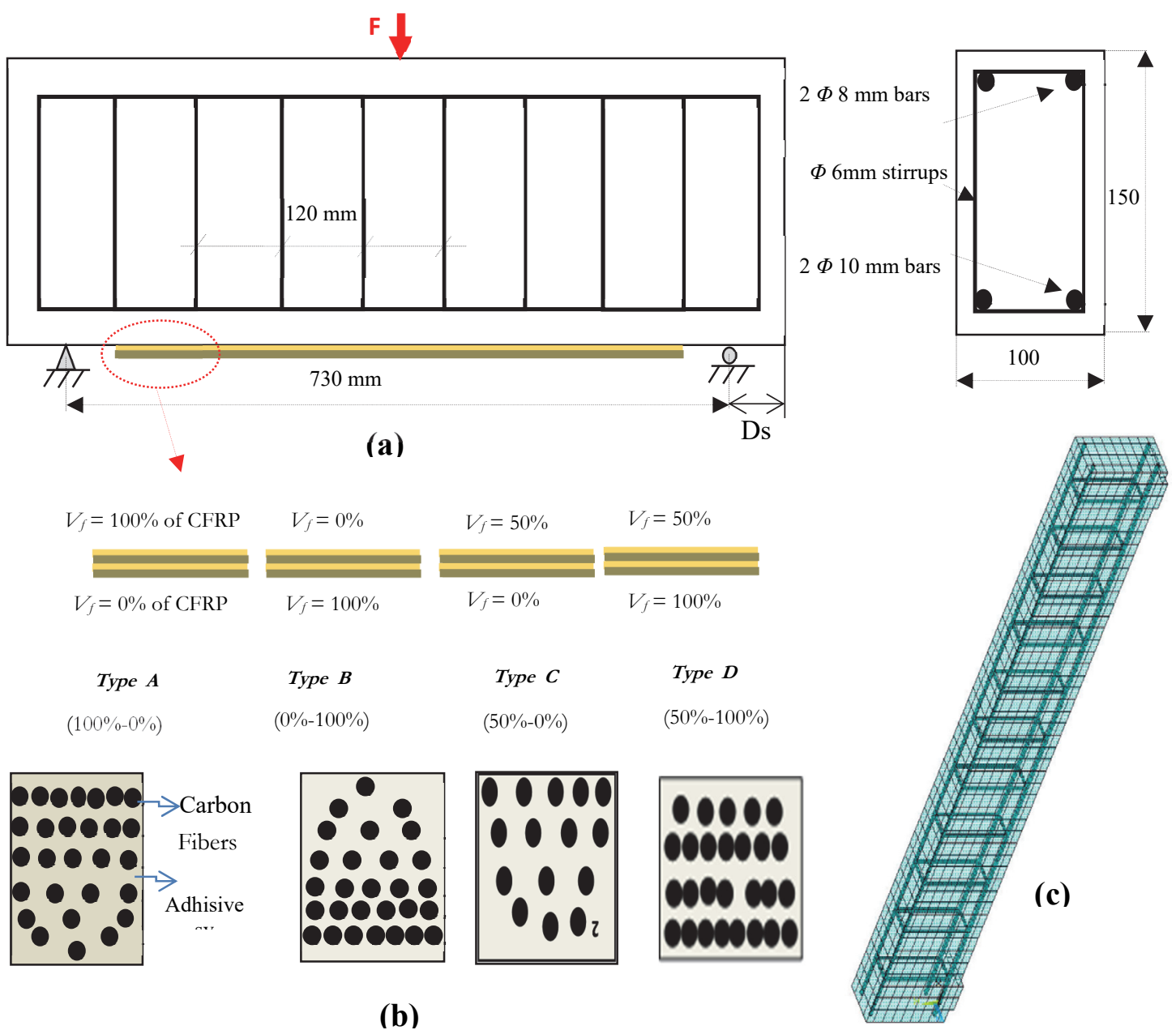

Figure 7: (a) Details of beam specimens, (b) Details of RC beams reinforced by FRPs plate, (c) Mesh of the concrete and reinforcement configuration.

In addition, a numerical analysis of the previously RC beams reinforced by FRPs plate were highlighted. Fig. $7 \mathrm{~b}$ presents a representative diagram of the different steps related to the transition from the reference beams (witness beam) to the rehabilitated beams (type A, B, C and D). The Solid65 element was used to model the concrete beam and Link8 elements were used to create the flexural and shear reinforcement. Reinforcement exists through the length of beam. Shear stirrups are modeled on a section normal to the length of the concrete beam. The finite element mesh for the reinforced concrete (RC) beam is shown in Fig. 7.c. In order to study the effect of reinforcing and its relative percentage value in concrete on the load-deflection response of concrete, the same dimensions and mechanical properties as those used by several authors $[10,39-40]$ were considered in this analysis and are given in Tab. 2. 


\begin{tabular}{cccccccc}
\hline $\mathrm{E}_{1}(\mathrm{GPa})$ & $\mathrm{E}_{2}(\mathrm{GPa})$ & $\mathrm{E}_{\mathrm{a}}(\mathrm{GPa})$ & $\mathrm{G}_{1}(\mathrm{GPa})$ & $\mathrm{G}_{2}(\mathrm{GPa})$ & $\tau_{\mathrm{f}}(\mathrm{MPa})$ & $\mathrm{K}_{\mathrm{b}}\left(\mathrm{MPa} / \mathrm{mm}^{2}\right)$ & $\mathrm{G}_{\mathrm{f}}(\mathrm{N} / \mathrm{mm})$ \\
25 & 230 & 3.8 & 10.41 & 5 & 1.8 & 160 & 0.5 \\
\hline
\end{tabular}

Table 2: Mechanical properties of the material used in this study [10, 39-40].

Fig. 8 show the effect of volume fraction $\left(V_{f}\right)$ of steel fiber on the concrete strength in terms of loading-deflection response. It can be found that the use of fiber regardless its volume fraction $(V)$ can improved the concrete properties. from this figure (Fig. 8), it is possible to analyze the stiffness of each beam. The initial deflection (at the beginning of loading) were practically the same for all beams, with a slightly higher stiffness for the reinforced beam with steel bars compared to witness beam. However, for level loading greater than $35 \mathrm{KN}$, the evolution of loading-deflection in the middle of the span began to show greater discrepancies between them especially for volume fraction of steel fiber $\mathrm{Vf}=$ $50 \%$ adjacent to the tension face of RC beams (type D; (50\%-100\%)). This can be explained by the fact that the adding of any fiber to cement and concrete, significantly improves the mechanical properties and prevents crack growth in mixed structures. Also the effect of crack and its size on the loading-deflection response are analyzed for the case of volume fraction of steel fiber (50\%-0\%) and are given in Fig. 8b. As can be clearly seen from this figure, that the ultimate load of the cracked beam is reduced significantly compared to the witness beam (without crack) for the same volume fraction of fiber in concrete. The level of ultimate load ranges from $39 \mathrm{kN}$ (crack equal to $100 \mathrm{~mm}$ ) to $52 \mathrm{kN}$ (without crack). This behavior can be explained probably by the fact that the presence of defect (crack) in any structure reduces the stiffness, strength and reliability of structures considerably. The same conclusion has been found by others authors [42-43].

(a)

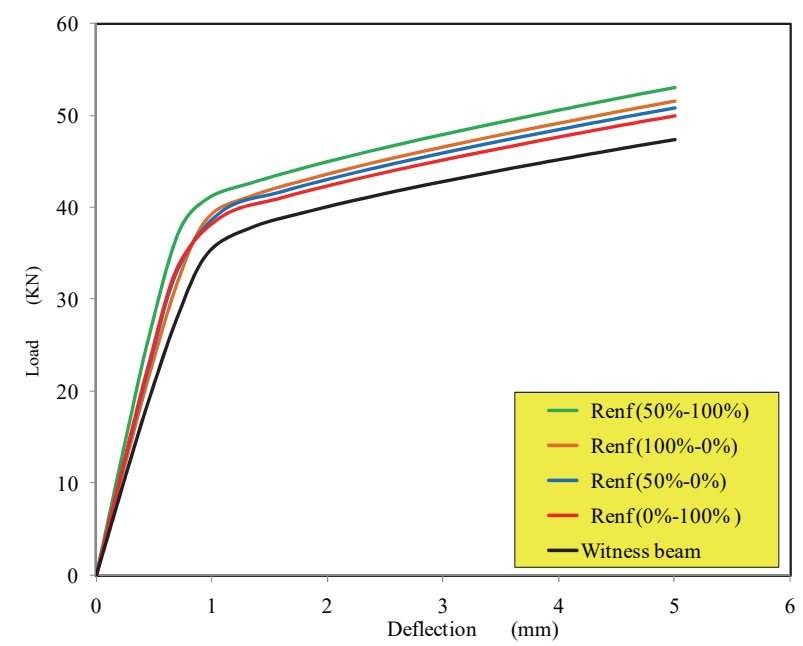

(b)

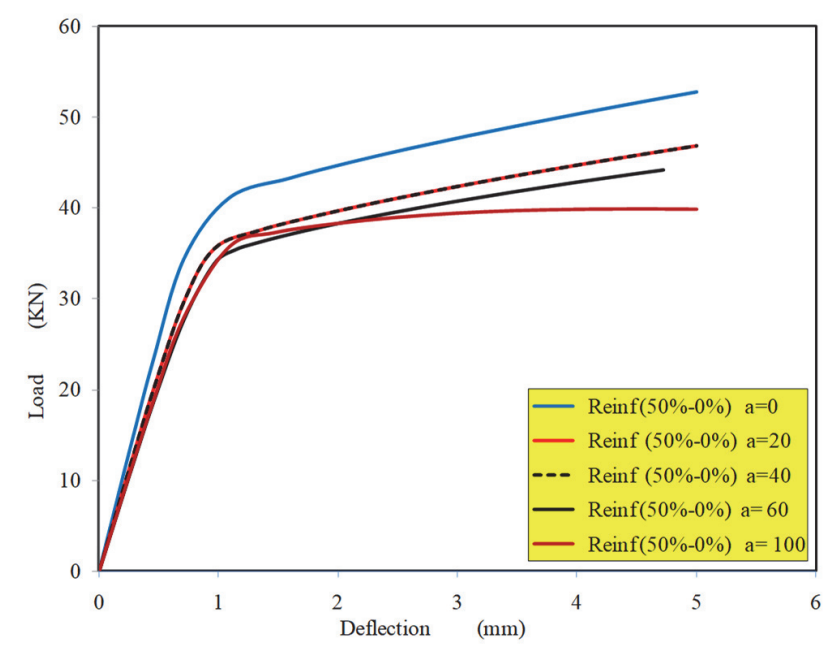

Figure 8: Comparison of the load vs. mid-span deflection of: (a) reinforced and unreinforced beam, (b) cracked and uncracked beam.

The evolution of loading versus deflection determined from the finite element results, with various volume fraction (type A, type B, type C and type D) of steel fiber in concrete and for four values of crack size (a = 20, 40, 60 and $100 \mathrm{~mm})$ are shown in Fig 9. Again the results show that the values of ultimate load are quite sensitive to the crack length with respect of each $V_{f}$ configuration. Indeed, the value of the ultimate load for high crack size (a $=100 \mathrm{~mm}$ ) is $80 \%$ times greater than a crack of small size $(\mathrm{a}=20 \mathrm{~mm})$ with respect the $V_{f}$ configuration. On the other hand, the results reveal that, for the same crack length the contents of fibers improves the concrete strength and the peak of flexural loads. We recall that the main characteristic of concrete is that the high compressive strength and low tensile strength (around 10\% of compressive strength). So, the steel bars are usually used in conjunction with concrete, where the bars absorb the tensile stresses during the service. In this study, the higher strengths were obtained for mixes that were manufactured with fiber volume fractions equal to 50\%-100\% (type D) whatever the crack size. In a recent study, Abbass et al. [44] indicated that concrete beams reinforced with steel fibers attained much higher ultimate load compared to the plain concrete (without reinforcing). 
(a)

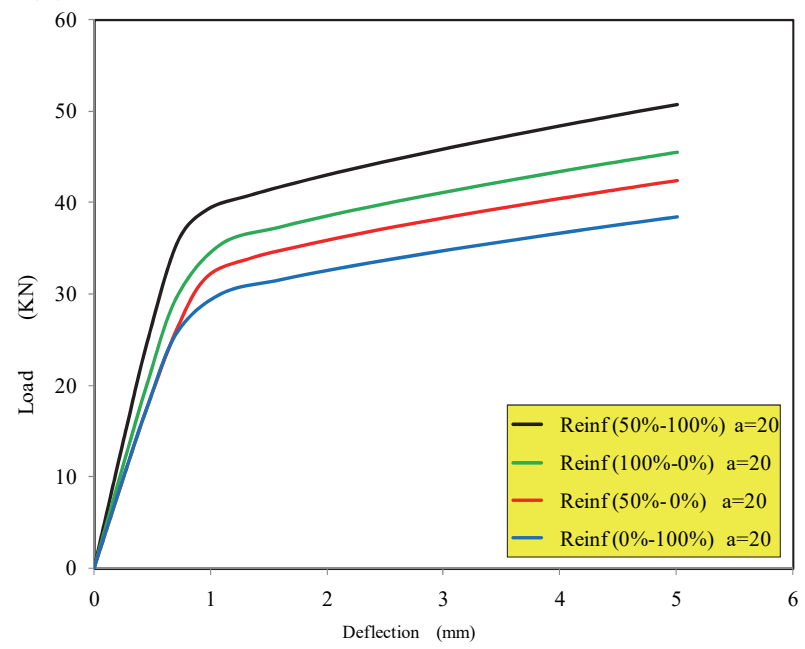

(c)

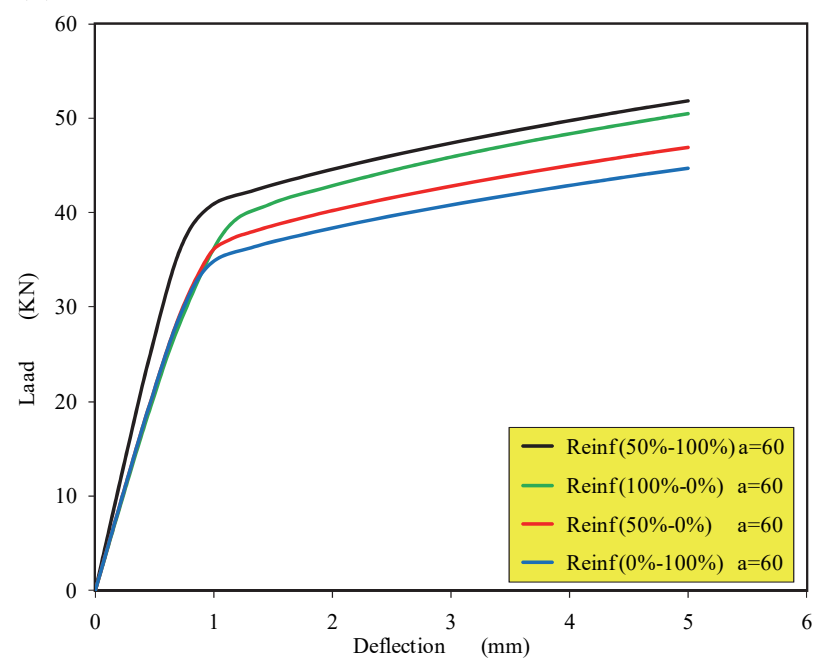

(b)

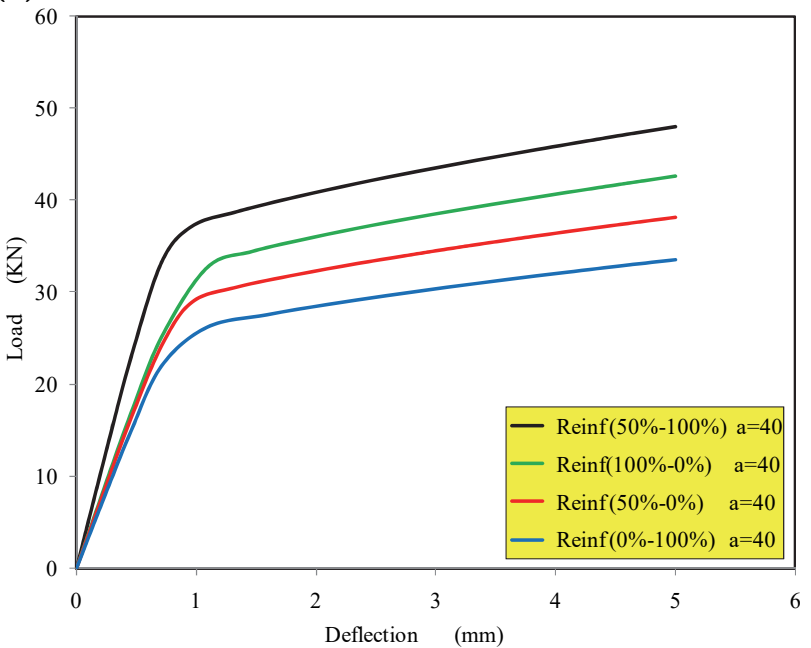

(d)

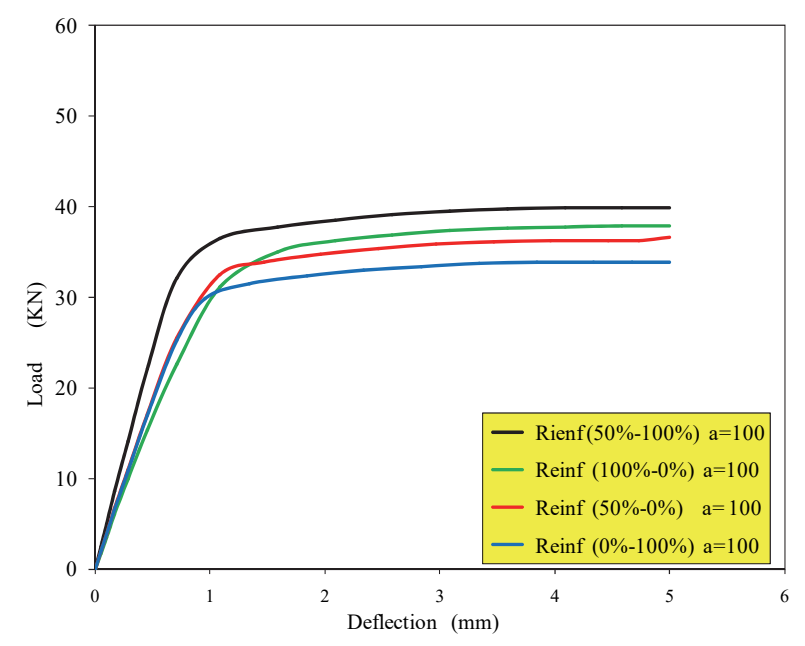

Figure 9: Comparison of the load vs. mid-span deflection of $V_{f}$ of reinforced cracked beams : (a) crack length $\mathrm{a}=20 \mathrm{~mm}$, (b) $\mathrm{a}=40$ $\mathrm{mm},(\mathrm{c}) \mathrm{a}=60 \mathrm{~mm}$ and $(\mathrm{d}) \mathrm{a}=100 \mathrm{~mm}$.

In this study, SOLID65 element is used for the modeling of the reinforced concrete beams. The particular feature of this element is that presents a tensile cracking and compressive crushing properties. The crack is represented by a circle while the crush is represented by an octahedron, both positioned perpendicular to the stress that generated the failure. If the crack opens and then closes, an " $\mathrm{X}$ " is inserted inside the circle as shown in Fig 10. There is also a color distinction, where red represents the first crack or crush, green represents the second crack and blue the third crack in the same node. This is in agreement with the finite element results of Kachlakev et al. [45] who concluded that there are different types of concrete failure that can occur are flexural cracks, compression failure (crushing), and diagonal tension cracks of reinforced concrete under four points bending load. We recall also, that the same conclusions were found by Bennegadi et al. [13] for the case of reinforcing concrete beam externally reinforced by HFRP plate.

\section{CONCLUSIONS}

7 he aim of this study is to analyse the effect of various parameters such as : geometrical and material properties on the flexural behaviours of repaired concrete beam and the fracture problems of mixed structural in civil engineering under three point bending condition, from these numerical results, we can deduce the following 
conclusions:

- The developed finite element modelling approach to simulate the reinforced concrete beams.

- The presence of crack regardless its size, reduces significantly the strength and reliability of structures.

- The presence of external bonding of FRP plates reduces the level of stress near the crack tip which can lead to increasing in the life time of structures in service.

- The increasing of the length of FRP reinforcement lead to increase of the ultimate load of the beam.

- Presence of steel fiber in concrete beam increases the ultimate load compared to witness beam (without reinforcement).

- The adding of steel fiber in concrete increases the ultimate load of concrete by about $15-30 \%$ for the same crack size.

- The finite element analysis can be used as numerical tool to predict the crack initiation in reinforced concrete.
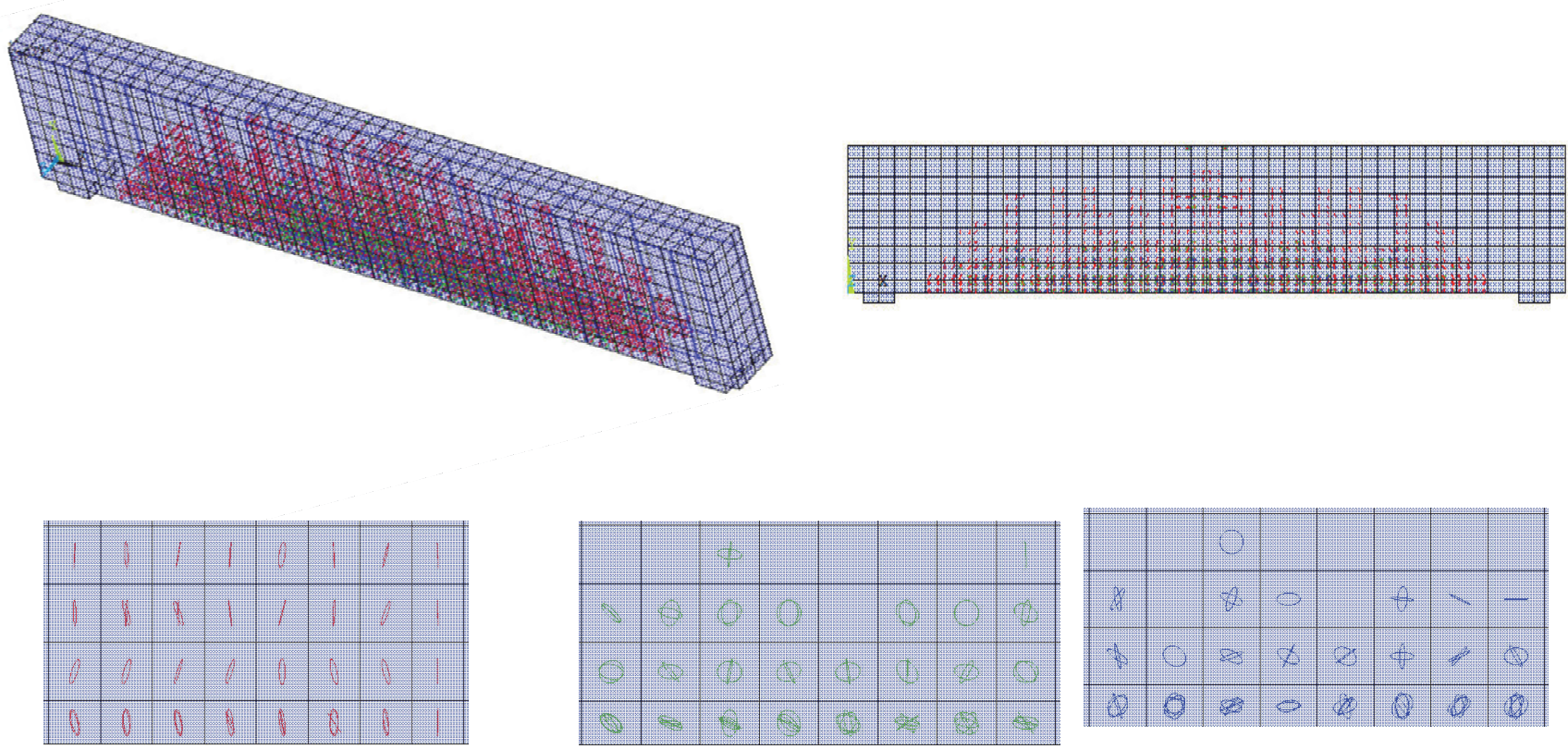

Figure 10: Numerical prediction of cracks pattern in the reinforced beam

\section{ACKNOWLEDGMENTS}

7 his research was supported by the Directorate General of Scientific Research and Technological Development (DGRSDT: General Directorate of Scientific Research and Technological Development) of Algeria. The authors warmly thank the scientific support of the two research teams from the Lille Mechanics Unit (France) and the LPQ3M Laboratory at Mustapha Stambouli University, Mascara, Algeria.

\section{REFERENCES}

[1] Benzaid, R., Mesbah, H., Chikh, N. (2010). FRP-confined Concrete Cylinders: Axial Compression Experiments and Strength Model. Journal of Reinforced Plastics And Composites, 29(16), pp. 2469-2488. DOI: $10.1177 / 0731684409355199$.

[2] Sereir, Z., Bennegadi, M. L., Amziane, S. (2013). Modèle d'optimisation du volume des plaques en FRP par MEF dans les structures renforcées en béton armé. 21ème Congrès Français de Mécanique. Bordeaux, 
http://hdl.handle.net/2042/52897.

[3] Tounsi, A., Hassaine Daouadji, T., Benyoucef, S., Adda Bedia, E. A. (2009) Interfacial stresses in FRP-plated RC beams: Effect of adherend shear deformations, Int. J. Adhes. Adhes., 29(4), pp. 343-351.

DOI: 10.1016/j.ijadhadh.2008.06.008.

[4] Benachour, A., Benyoucef S., Tounsi A., (2008). Interfacial stress analysis of steel beams reinforced with bonded prestressed FRP. J. Eng. Struc. 30, pp. 3305-3315. DOI: 10.1016/j.engstruct.2008.05.007.

[5] Sebastian, W.M. (2006). Optimization of flexural stiffness profiles to compensate for reduced ductility in hyperstatic reinforced concrete structures, Engineering Structures, 28, pp. 893-902. DOI:10.1016/j.engstruct.2005.10.014.

[6] Perera, R., Barchín, M., Arteaga, A., De Diego, A., (2010). Prediction of the ultimate strength of reinforced concrete beams FRP-strengthened in shear using neural networks. Composites: Part B 41. pp. 287-298. DOI:10.1016/j.compositesb.2010.03.003.

[7] Kato, J., Ramm, E. (2010). Optimization of fiber geometry for fiber-reinforced composites considering damage. Finite Elements in Analysis and Design 46. pp. 401-415. DOI:10.1016/j.finel.2010.01.001.

[8] Bruggi, M., Taliercio, A. (2013). Topology optimization of the fiber-reinforcement retrofitting existing structures. International Journal of Solids and Structures 50. pp. 121-136. DOI: 10.1016/j.jijsolstr.2012.09.009.

[9] Madi R., Guenfoud M., (2013). Renforcement des poteaux rectangulaires en béton armé par PRF. 21ème Congrès Français de Mécanique. Bordeaux, 26 au 30 août 2013. http://hdl.handle.net/2042/52245.

[10] Hadjazi, K., Sereir, Z., Amziane, S. (2012). Cohesive zone model for the prediction of interfacial shear stresses in a composite-plate RC beam with an intermediate flexural crack. Composite Structures 94. pp. 3574-3582.

DOI: $10.1016 /$ j.compstruct.2012.05.027.

[11] Lusis, V., Krasnikovs, A., Kononova, O., Lapsa, V.A., Stonys, R., Macanovskis, A., Lukasenoks, A. (2017). Effect of short fibers orientation on mechanical properties of composite material- fiber reinforced concrete. Journal of Civil Engineering and Management. 23(8). pp. 1091-1099. DOI: 10.3846/13923730.2017.1381643.

[12] Spadea, G., Swamy, R. N., Asce, F., Bencardino, F. (2001). Strength and ductility of RC beams repaired with bonded CFRP laminates. Journal of Bridge Engineering. 6(5). pp. 349-355. DOI: 10.1061/(ASCE)1084-0702(2001)6:5(349).

[13] Bennegadi, M.L., Sereir, Z., Amziane, S., (2013). 3D nonlinear finite element model for the volume optimization of a RC beam externally reinforced with a HFRP plate. Construction and Building Materials 38. pp. 1152-1160. DOI: $10.1016 /$ j.conbuildmat.2012.09.012

[14] Wu, Z. (2005). Structural strengthening and integrity with hybrid FRP composites. FRP Composites in Civil Engineering - CICE 2004 - Edition Taylor \& Francis Group, London.

[15] Khomwan, N., Foster, S.J., Smith, S.T. (2005). Debonding failure in CFRP strengthened concrete beams. FRP Composites in Civil Engineering - CICE 2004 - Edition Taylor and Francis Group, London.

[16] Ceroni, F. (2010). Experimental performances of RC beam strengthened with FRP materials. Construction and Building Materials 24. pp. 1547-1559. DOI: 10.1016/j.conbuildmat.2010.03.008.

[17] Toutanji, H. A., El-Korchi, T., Katz, R. N., Leatherman, G. L. (1993). Behaviour of carbon fiber reinforced cement composites in direct tension. Cement and Concrete Research. 23(3). pp. 618-626. DOI: 10.1016/0008-8846(93)90013-Y.

[18] Shahawy, M., Chaallal, O., Beitelman, Te and El-Saad, A. (2001). Flexural strengthening with carbon fibre-reinforced polymer composite of preloaded full-scale girders, Structural Journal, 98(5), pp. 735-742. https://www.concrete.org/.

[19] Attari, N., Amziane, S., Chemrouk, M. (2012). Flexural strengthening of concrete beams using CFRP, GFRP and hybrid FRP sheets. Construction and Building Materials 37. pp. 746-757. DOI: 10.1016/j.conbuildmat.2012.07.052

[20] Hashemi, S. and Al-Mahaidi, R. (2012), Experimental and finite element analysis of flexural behavior of FRPstrengthened RC beams using cement-based adhesives. Construction and Building Materials 26. pp. 268-273.

DOI: 10.1016/j.conbuildmat.2011.06.021

[21] Kermiche, S., Redjel, B. Jr. (2012). Analyse expérimentale et analytique du comportement en flexion des poutres en béton armé pré fissurées renforcées par un matériau composite en toile de fibres de carbone (TFC). Synthèse: Revue des Sciences et de la Technologie, $25:$ pp. 41-58 . https://www.asjp.cerist.dz/en/article/42524

[22] Tabatabaei, Z. S., Volz, J. S., Keener, D. I., Gliha B. P., (2014). Comparative impact behavior of four long carbon fiber reinforced concretes. Materials and Design 55. pp. 212-223. DOI: 10.1016/j.matdes.2013.09.048

[23] Narmashiri, K., Sulong, N.H.R., Jumaat, M.Z. (2012). Failure analysis and structural behaviour of CFRP strengthened steel I-beams. Construction and Building Materials 30. pp. 1-9. DOI: 10.1016/j.conbuildmat.2011.11.009

[24] Hallonet, A., Ferrier E., Michel L., Benmokrane B., (2019). Durability and tensile characterization of wet lay-up flax/epoxy composites used for external strengthening of RC structures. Construction and Building Materials 205. pp. 679-698. DOI: 10.1016/j.conbuildmat.2019.02.040 
[25] Asgarinia S., Viriyasuthee, C., Phillips, S., Dubé, M., Baets, J., Vuure, A.V., Verpoest, I., Lessard, L., (2015). Tensiontension fatigue behaviour of woven flax/epoxy composites. Journal of Reinforced Plastics and Composites, 34(11). pp. 857-867. DOI: $10.1177 / 0731684415581527$

[26] Ivanova, I., Assih, J., (2015). Static and dynamic experimental study of strengthened reinforced short concrete corbel by using carbon fabrics, crack path in shear zone. Frattura ed Integrità Strutturale, 34. pp. 90-98. DOI: $10.3221 /$ IGF-ESIS.34.09.

[27] Reddy, C.M.K., Ramesh, B., Macrin, D., (2020). Effect of crystalline admixtures, polymers and fibers on self healing concrete - a review. Materials Today: Proceedings. DOI: 10.1016/j.matpr.2020.06.122 (article in press)

[28] Zhang, P., Li, Q.F., (2013). Effect of polypropylene fiber on durability of concrete composite containing fly ash and silica fume. Composites: Part B 45. pp. 1587-1594. DOI: 10.1016/j.compositesb.2012.10.006

[29] Ardalan, R.B., Joshaghani, A., Hooton, R.D. (2017). Workability retention and compressive strength of selfcompacting concrete incorporating pumice powder and silica fume. Construction and Building Materials 134. pp. 116-122. DOI: 10.1016/j.conbuildmat.2016.12.090.

[30] Uysal, M., Yilmaz, K., Ipek, M. (2012). Properties and behavior of self-compacting concrete produced with GBFS and FA additives subjected to high temperatures. Construction and Building Materials 28. pp. 321-326. DOI: 10.1016/j.conbuildmat.2011.08.076.

[31] Lijuan, L., Shenghua, R., Lan, Z. (2014). Mechanical properties and constitutive equations of concrete containing a low volume of tire rubber particles. Construction and Building Materials 70. pp. 291-308. DOI: 10.1016/j.conbuildmat.2014.07.105.

[32] Bompa, D.V., Elghazouli, A.Y., Xu, B., Stafford, P.J., Ruiz-Teran, A.M., (2017). Experimental assessment and constitutive modelling of rubberised concrete materials. Construction and Building Materials 137. pp. 246-260. DOI: 10.1016/j.conbuildmat.2017.01.086.

[33] Peterson, P.E., (1980). Fracture energy of concrete: Method of determination. Cement and Concrete Research 10(1). pp. 79-89. https://doi.org/10.1016/0008-8846(80)90054-X

[34] Bažant, Z.P., and Giraudon, E.B. (2002). Statistical prediction of fracture parameters of concrete and implications for choice of testing standard. Cement and Concrete Research 32. pp. 529-556. DOI: 10.1016/S0008-8846(01)00723-2.

[35] Planas, J., and Elices M. (1990). Fracture criteria for concrete: Mathematical approximations and experimental validation. Engineering Fracture Mechanics, 35(1-3). pp. 87-94. DOI: 10.1016/0013-7944(90)90186-K.

[36] ASTM C469-02. Standard test method for static modulus of elasticity and Poisson ratio of concrete in compression. Annual book of ASTM standards, 04.02.

[37] Wu, Z., and Niu, H. (2007). Prediction of crack-induced debonding failure in R/C structures flexurally strengthened with externally bonded FRP composites. Doboku Gakkai Ronbunshuu E 63(4). pp 620-639. DOI: $10.2208 /$ jsceje.63.620.

[38] ANSYS 19.0, Ansys Inc. Documentation, ANSYS Elements Reference, (2019).

[39] Wu Z., Yin J., (2003). Fracturing behaviors of FRP-strengthened concrete structures. Engineering Fracture Mechanics 70. pp. 1339-1355. DOI: 10.1016/S0013-7944(02)00100-5.

[40] Wang, J. (2006). Cohesive zone model of intermediate crack-induced debonding of FRP-plated concrete beam. International Journal of Solids and Structures 43. pp. 6630-6648. DOI:10.1016/j.ijsolstr.2006.01.013.

[41] Gao, B., Leung, C.K.Y., Kim, J.K., (2007). Failure diagrams of FRP strengthened RC beams. Composite Structures 77. pp. 493-508. DOI:10.1016/j.compstruct.2005.08.003.

[42] Kristiawan, S., Supriyadi, A., Sangadji, S., Santosa, D. (2017). Cracking behaviour and its effect on the deflection of patched-reinforced concrete beam under flexural loading. MATEC Web of Conferences 138, 02021 (2017) . EACEF 2017. DOI: $10.1051 /$ matecconf/201713802021.

[43] Elrakib, T.M., Arafa, A.I. (2012). Experimental evaluation of the common defects in the execution of reinforced concrete beams under flexural loading. HBRC Journal 8. pp. 47-57. DOI: 10.1016/j.hbrcj.2012.08.006.

[44] Abbass, W., Khan, M.I., Shehab Mourad, S. (2018). Evaluation of mechanical properties of steel fiber reinforced concrete with different strengths of concrete. Construction and Building Materials 168. pp. 556-569.

DOI: 10.1016/j.conbuildmat.2018.02.164.

[45] Kachlakev, D., Miller, T., Yim, S. (may 2001). Finite element modeling of reinforced concrete structures strengthened with FRP laminates. California Polytechnic State University, San Lius Obispo, CA and Oregon State University, Corvallis, OR for Oregon Department of Transportation. 


\section{NOMENCLATURE}

$\mathrm{B}$

FRP

CFRP

HFRP

Ds

$\mathrm{e}_{\mathrm{a}}$

ep

$\mathrm{E}_{\mathrm{c}}=\mathrm{E}_{1}$

$\mathrm{E}_{\mathrm{s}}$

$\mathrm{E}_{\mathrm{a}}$

$\mathrm{E}_{2}$

$\mathrm{F}_{\mathrm{V}}$

$\mathrm{f}_{\mathrm{c}}$

$\mathrm{F}_{\mathrm{V}}(100 \%-50 \%)$

$\mathrm{F}_{\mathrm{V}}(0 \%-100 \%)$

$\mathrm{F}_{\mathrm{V}}(100 \%-0 \%)$

$\mathrm{G}_{1}$

$\mathrm{G}_{2}$

$\mathrm{K}_{\mathrm{b}}$

$\mathrm{U}$

$\mathrm{U}_{\mathrm{x}}$

$\mathrm{U}_{\mathrm{z}}$

$\tau_{\mathrm{f}}$

W

L

$\mathrm{G}_{\mathrm{F}}$

$G_{f}$
Crack length

Thickness of the specimen

Fiber-reinforced polymers

Carbon fiber-reinforced polymers

Hybrid fiber-reinforced polymers

The space between the beam boundary and the support

Glue layer thickness

Patch layer thickness

Concrete Young's modulus

Steel young's modulus

Glue layer Young's modulus

Carbon fibers Young's modulus

Fractional fiber volume

concrete compressive strength

Orientation rate of the volume fraction from $50 \%$ to $100 \%$

Orientation rate of the volume fraction from $0 \%$ to $100 \%$

Orientation rate of the volume fraction from $100 \%$ to $0 \%$

The transverse shear modulus of adherents 1

The transverse shear modulus of adherents 2

Initial elastic stiffness of the FRP-concrete interface

Displacement

Displacement following the $\mathrm{x}$ axis

Displacement following the $Z$ axis

Shear strength of the interface

Height of the concrete specimen

length of the concrete specimen

Fracture energy for Bažant's model

Fracture energy for cohesive crack model 